\title{
Peningkatan Pengetahuan Pola Makan Sehat melalui Flash Card
}

\section{Zubaedah dan Dwi Puji Lestari}

STAI Al Aqidah Al Hasyimiah Jakarta

Email: idazubaedah717@yahoo.com

\begin{abstract}
The purpose of this research was to determinate the proccess of implementation flasch card to increase knowledge of healty dietary habit in Group B Al Hub Kebayoran Baru South of Jakarta. This research is an action research which refers to the model of a classroom Action Research Kemmis and Mc. Taggart. The subject of this research are children in Group B Al Hub Kebayoran Baru South of Jakarta there are 10 children. The steps of this research : (1) Planing (2) Action (3) Observation (4) Reflection. Data analysis used quantitative and qualitative. Data analysis qualitative used Miles and Hubberman model. This research do in two cycles, there are cycle I and II. The end result of the overall analysis of the data is the percentage in $91,17 \%$ cycles II which showed from precycle is $29,37 \%$ up to cycles I $61,94 \%$.
\end{abstract}

Keywords: Healthy Dietary Habit, flash card And Action Research 


\section{PENDAHULUAN}

Anak usia dini merupakan salah satu periode usia manusia. Pada periode ini anak berkembang sangat pesat, dari segi pertumbuhan maupun segi perkembangan. Usia 4-6 tahun aktifitas mereka lebih banyak. Golongan ini sangat rentan terhadap penyakit kurang gizi dan penyakit infeksi. Gizi merupakan dasar dari kesehatan dan perkembangan anak, gizi yang baik mengindikasikan sistim kekebalan tubuh anak yang baik pula. Akibat kurang gizi secara umum menyebabkan gangguan pada proses-proses yaitu: (1) anak tidak tumbuh menurut potensinya, (2) anak kekurangan tenaga dalam bergerak dan beraktivitas, dan (3) sistim imunitas dan antibodi pada anak berkurang, kemampuan berfikir dan perkembangan otak tidak optimal (Sunita Almatsier, 2001: 11). Kekurangan gizi dapat menghambat perkembangan anak.Agar perkembangan tidak terganggu maka gizi anak harus diperhatikan.

Untuk memenuhi zat gizi yang dibutuhkan, mengkonsumsi makanan yang bervariasi harus dilakukan karena tidak ada satu jenis makanan yang mengandung semua zat gizi yang diperlukan dalam jumlah yang seimbang.Jadi diperlukan berbagai jenis makanan, karena zat gizi tersebar luas dalam makanan yang berbeda-beda. Menurut fungsinya, zat gizi dikelompokan menjadi tiga, yaitu zat gizi yang berperan sebagai sumber energi (zat pembakar), zat gizi yang berperan dalam pertumbuhan dan pemeliharaan jaringan tubuh (zat pembangun), serta zat gizi yang berperan dalam pengatur proses tubuh (zat pengatur). Oleh karenanya akan sangat mendukung jika makanan yang dikonsumsi bervariasi sehingga terpenuhinya kebutuhan akan zat gizi tersebut dalam jenis makanan yang berbeda.

Pada umumnya masalah yang sering dialami anak usia dini adalah masalah kesehatan, kurang gizi, pola makan, kurang olah raga dan pelecehan. Pada usia4-6 tahun, anak bersifat konsumen aktif, yaitu mereka dapat memilih makanan yang disukai, kepada mereka dapat diberikan pengetahuan pola makan sehat di sekolah maupun di rumah. Pengetahuan akan pola makan sehat yang didapat oleh anak akan membentuk kebiasaan yang baik. Kebiasaan yang baik sudah harus ditanamkan sedini mungkin (Persatuan Ahli Gizi Indonesia, 1997: 8). Internalisasi pengetahuan akan pola makan sehat diperlukan untuk menunjang pertumbuhan dan perkembangan anak sehingga asupan gizi yang masuk akan terjaga. 
Anak taman kanak-kanak (TK) merupakan salah satu segmen penting dalam masyarakat yang perlu diperhatikan sudut pengetahuan apa itu pola makan sehat, karena pola makan sehat yang biasa dikonsumsi sejak masa taman kanak-kanak akan membentuk pola kebiasaan makan selanjutnya. Anak TK selain masih dalam proses pertumbuhan dan pengenalan lingkungan, mereka termasuk rawan terhadap pengaruh makanan dan minuman modern (DEPKES RI, 1997). Promosi melalui media elektronik maupun cetak merupakan pengaruh yang cukup besar dalam pembentukan perilaku makan anak. Anak ingin mencoba makanan yang diiklankan di media elektonik, akibatnya anak lebih memilih minuman soft drinks daripada jus buah, anak lebih memilih makanan fast food daripada makanan yang dimasak di rumah.

Berdasarkan pengamatan yang peneliti lakukan di kelompok BTK Al Hub Kebayoran baru ada beberapa masalah terkait dengan pengetahuan pola makan sehat diantara: (1) $60 \%$ anak hanya suka makan dengan dua jenis makanan saja, misalnya nasi dengan ayam; (2) 70\% anak tidak suka dengan sayur; (3) $50 \%$ anak tidak menyukai tahu dan tempe; (4) $80 \%$ anak menyukai mie instan; dan (5) $80 \%$ menyukai susu kemasan rasa cokelat dan strobery. Berdasarkan wawacara yang dilakukan dengan kepala sekolah, hal tersebut terjadi karena ibu-ibu di Jakarta adalah pekerja diluar rumah maka mereka menyediakan makanan siap saji dan ketidak tahuan anak mengenai pola makan sehat sehingga mereka terpola untuk menyukai makanan tersebut tanpa memperhatikan kesehatannya.

Hal ini yang mendasari munculnya gagasan untuk melakukan penelitian pada anak usia dini dalam peningkatan pengetahuan pola makan sehat melalui flash card yang dilaksanakan di kelompok B Al Hub Kebayoran baru. Jakarta Selatan, Maka dari itu diduga bahwa flash card dapat meningkatkan pengetahuan pola makan sehat.

\section{DISKUSI}

\section{Pengetahuan Pola Makan Sehat}

Notoatmojo mengemukakan bahwa pengetahuan merupakan hasil "tahu" dan ini terjadi setelah orang melakukan penginderaan terhadap objek tertentu (Soekidjo Notoatmojo, 2003: 8). Senada dengan Surajiyo mengatakan bahwa pengetahuan adalah suatu istilah yang dipergunakan untuk 
menuturkan apabila seseorang mengenal tentang sesuatu (Surajiyo, 2013: 60). Lain halnya dengan Suriasumantri yang mengatakan bahwa pengetahuan pada hakikatnya merupakan segenap apa yang kita ketahui tentang suatu objek tertentu, termasuk didalamnya adalah ilmu (Jujun S. Suriasumantri, 2005: 104). Dari ketiga pendapat tokoh tersebut maka pengetahuan adalah hasil tahu dari proses pengindaraan seseorang sehinga terjadi perubahan dari yang tidak tahu menjadi tahu.

Baliwati, dkk mengatakan pola makan atau pola konsumsi pangan adalah susunan jenis dan jumlah makanan yg dikonsumsi seseorang atau sekelompok orang pada waktu tertentu (Yayuk Farida Baliwati, dkk., 2004: 95). Maka pola makan adalah komposisi makanan yang hendak dikomsumsi seseorang pada waktu tertentu. Senada dengan Santoso dan Ranti mengungkapkan bahwa pola makan merupakan bagian informasi yang memberi gambaran mengenai macam dan jumlah bahan makanan yang dimakan tiap hari oleh satu orang dan merupakan ciri khas untuk suatu kelompok masyarakat tertentu (Soegeng Santoso dan Anne Lies Ranti, 2004: 115). Keduanya mengungkapkan bahwa pola makan merupakan informasi yang mengambarkan perencanaan makanan yang hendak dikonsumsi baik itu mengenai jenis makanan dan jumlah makanan yang menjadi ciri khas masyarakat tertentu. Sehingga pola makan adalah komposisi makanan yang hendak dikomsumsi yang mengambarkan ragam jenis dan jumlah makanan seseorang pada waktu tertentu.

Makanan sehat yaitu makanan yang memiliki kandungan gizi seimbang, mengandung serat dan zat-zat yang diperlukan tubuh untuk proses tumbuh kembang. Hal ini ditegaskan oleh Almatsier, makanan sehat adalah makanan yang mengandung empat sehat lima sempurna, yaitu karbohidrat, protein, vitamin, mineral dan susu (Sunita Almatsier, 20011: 289). Kandungan dari makanan sehat adalah makanan yang berserat gizi seimbang dan zat-zat yang diperlukan tubuh atau lebih mudahnya adalah makanan yang terdiri dari empat sehat lima sempurna yakni karbohidrat, protein, vitamin, mineral dan susu.

Dari berbagai pemaparan di atas dapat simpulkan bahwa pengetahuan pola makan sehat adalah hasil "tahu" yang melalui proses pengindraan seseorang mengenai mengenai komposisi makanan yang hendak dikomsumsi yang 
didalamnya mengambarkan ragam jenis dan jumlah makanan yang mengandung gizi seimbang, berserat dan zat-zat yang diperlukan oleh tubuh kandungan tersebut terdiri dari dari empat sehat lima sempurna yakni karbohidrat, protein, vitamin, mineral dan susu pada waktu tertentu.

\section{Flash Card}

Masyarakat semakin menyadari betapa pentingnya pendidikan untuk anak usia dini. Hal ini nampak dengan berkembangnya tempat pendidikan anak usia dini formal, informal, dan non formal di seluruh indonesia, ada yang berbentuk tempat penitipan anak, kelompok bermain, atau taman bermain, taman kanak-kanak dan pendidikan anak usia sejenis. Pentingnya pendidikan anak usia dini, menuntut pendekatan yang akan digunakan dalam kegiatan pembelajaran yang memusatkan perhatian pada anak.

Dalam pertemuan Forum Pendidikan Dunia tahun 2000 di Dakkar, Senegal, telah menghasilkanenam kesepakatan sebagai kerangka aksi pendidikan untuk semua yang salah satu butirnya menyatakan:"memperluas dan memperbaiki keseluruhan perawatan dan pendidikan anak usia dini (PAUD), terutama bagianak-anak yang sangat rawan dan kurang beruntung. Anggapan bahwa pendidikan baru bisa dimulai setelah usia sekolah dasar yaitu usia tujuh tahun ternyata mengembangkan kepribadian dan jati dirinya. Dengan pemberdayaan yang baik pada usia dini, akan dihasilkan anakanak yang masa depannya cerah karena mereka menjadi orang dewasa yang kreatif dan mempunyai rasa percaya diri yang kuat. Kendalanya di Indonesia adalah bahwa tidak setiap orang tua punya pengetahuan dan kesiapan untuk mendidik anaknya secara betul.Seorang ibu memang telah memiliki "asam garam" dalam mengasuh anak-anak mereka, akan tetapi agarperkembangan potensi anak berjalan maksimal anak usia 0 - 4 tahun mencapai 50\% (Cropley, 94). Artinya bila pada usia tersebut otak anak tidak mendapatkan rangsangan yang maksimal maka Otak anak tidak akan berkembang secara optimal. Hasil penelitian di Baylor College of Medicine menyatakan bahwa lingkungan memberi peran yang sangat besar dalam pembentukan sikap, kepribadian, dan pengembangan kemampuananak secara optimal. Anak yang tidak mendapat lingkungan baik untuk merangsang pertumbuhan Otak nya,misal jarang disentuh, jarang kecil 20 - 30\% dari ukuran normal seusianya (Depdiknas, 2003:1). 
Secara keseluruhan hingga usia delapan tahun, 80\% kapasitas kecerdasan manusia sudah terbentuk, artinya kapasitas kecerdasan anak hanya bertambah $30 \%$ setelah usia empat tahun hingga mencapai usia delapan tahun.Selanjutnya kapasitas kecerdasan anak tersebut akan mencapai 100\% setelah berusia sekitar 18 tahun (Abdulhak, 2002).

Media Pembelajaran PAUD adalah semua hal yang dapat digunakan sebagai penyalur pesan dari pengirim ke penerima untuk merangsang fikiran, perasaan, perhatian dan minat, serta perhatian anak sehingga proses belajar terjadi.

Pesan berupa isi ajaran dan didikan yang ada di kurikulum dituangkan oleh Pendidik PAUD atau sumber lain kedalam media dalam bentuk-bentuk simbol komunikasi baik simbol verbal (kata-kata lisan atau tertulis) maupun simbol non verbal atau visual. Selanjutnya penerima pesan (bisa siswa atau Pendidik) menafsirkan simbol-simbol komunikasi tersebut sehingga diperoleh pesan.

Peran media dalam pembelajaran khususnya dalam pendidikan anak usia dini semakin penting artinya mengingat perkembangan anak pada saat itu berada pada masa berfikir konkrit. Oleh karena itu salah satu prinsip pendidikan untuk anak usia dini harus berdasarkan realita artinya bahwa anak diharapkan dapat mempelajari sesuatu secara nyata.

Pendidikan untuk anak usia dini harus menggunakan sesuatu yang memungkinkan anak dapat belajar secara konkrit. Prinsip tersebut mengisyaratkan perlunya digunakan media sebagai saluran penyampai pesan-pesan pendidikan untuk anak usia dini

Flashcard adalah kartu kecil yang berisi gambar, teks, atau tanda simbol yang mengingatkan atau mengarahkan siswa kepada sesuatu yang berhubungan dengan gambar. Flashcard biasanya berukuran $8 \times 12 \mathrm{~cm}$, atau dapat disesuaikan dengan besar kecilnya kelas yang dihadapi (Azhar Arsyad, 2011:119-120). Senada yang dikemukakan oleh Rudi Susilana dan Cepiriyana flashcard merupakan media pembelajaran yang berupa kartu bergambar berukuran $25 \mathrm{X}$ $30 \mathrm{~cm}$. Gambar-gambar pada flashcard merupakan serangkaian pesan yang disajikan dengan adanya keterangan pada setiap gambar.

Begitu juga Dini Indriana mengungkapkan bawa flashcard adalah media pembelajaran dalam bentuk kartu bergambar 
yang ukurannya seukuran postcard atau sekitar $25 \times 30 \mathrm{~cm}$ (Dina Indriana, 2011: 64). Dari ketiga sumber tersebu disimpulkan bahwa flash card adalah media pembelajaran berupa kartu kecil yang berisi gambar, teks atau tanda simbol yang dapat berukuran $8 \times 12 \mathrm{~cm}$ atau $25 \times 30 \mathrm{~cm}$ yang dapat digunakan untuk menyampaikan pesan sesuai yang ada dalam isi kartu tersebut.

Penelitian ini merupakan metode penelitian tindakan yang menggunakan model Kemmis dan Taggart. Yang terdiri dari empat komponen, yaitu: perencanaan (planning), tindakan (acting), pengamatan (observing), dan refleksi (reflecting). Tekhnik pengumpulan data dalam penelitian ini adalah menggunakan: (a) Observasi Pemantau Tindakan pada anak dan guru, (b) Wawancara, dan (c) Dokumentasi. Jenis instrumen yang digunakan adalah menggunakan non tes berupa lembar observasi, yang terdiri dari, lembar observasi pemantauan tindakan.

Teknik analisis data yang dilakukan dalam penelitian ini adalah melalui dua cara yaitu teknik analisis kuantitatif deskriptifdan data kualitatif. Statistika deskriptif untuk membandingkan hasil yang diperoleh dari siklus pertama dan siklus kedua berupa rata-rata angka hitung (mean) dan perhitungan/pengukuran berbentuk prosentase. Analisis data kualitatif dilakukan terhadap data yang dikumpulkan melalui wawancara, catatan lapangan peneliti, dan refleksi. Analisis data kualitatif mengunakan teknik menurut Miles dan Hubermanyang terdiri dari: data reduction, data display, data conclusing drawing/verification.

Hasil penelitian dan pembahasan menunjukkan bahwa pengetahuan pola makan sehat meningkat dari tiap siklusnya berikut adalah deskripsi dari kegiatan pra siklus hingga siklus II.

\section{Pra-Siklus}

Dari data pengetahuan pola makan sehat pada anak prapenelitian dapat disajikan dalam bentuk grafik maka hasilnya sebagai berikut: 


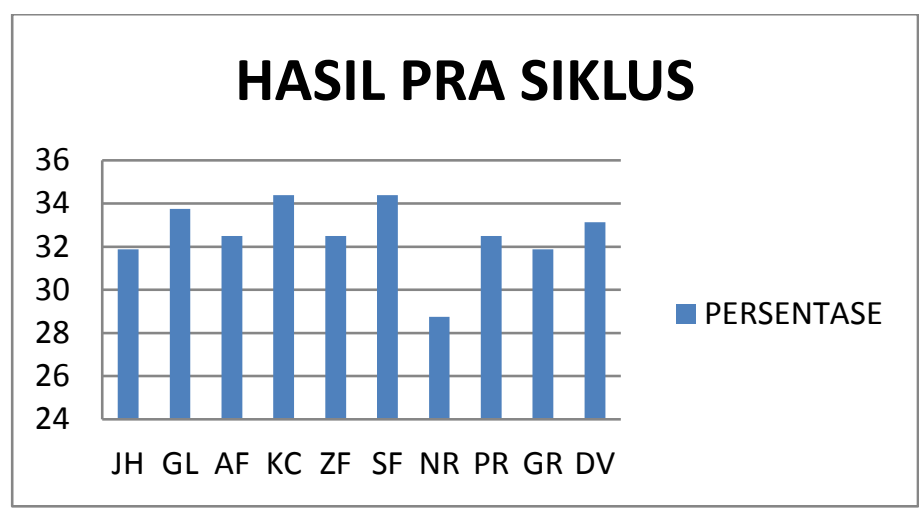

Gambar 1. Grafik Pengetahuan Pola Makan Sehat

Grafik tersebut di atas mengambarkan bahwa pengetahuan pola makan sehat di TK B AL Hub, Kebayoran Baru, Jakarta Selatan yaitu persentase $32,57 \%$. Setelah mengetahui hasil kemudian peneliti bersama kolaborator melakukan analisis dan berdiskusi tentang hasil dari assesmen pra siklus. Setelah dianalisa secara mendalam. Maka peneliti dan kolaborator memutuskan untuk melaksanakan tindakan intervensi yaitu pelaksanaan siklus I karena nilai hasil assesmen pra siklus berada dibawah das sein dan masih jauh dari standarkeberhasilan yang telah disepakati antara kolaborator dan peneliti yakni $71 \%$.

\section{Siklus I}

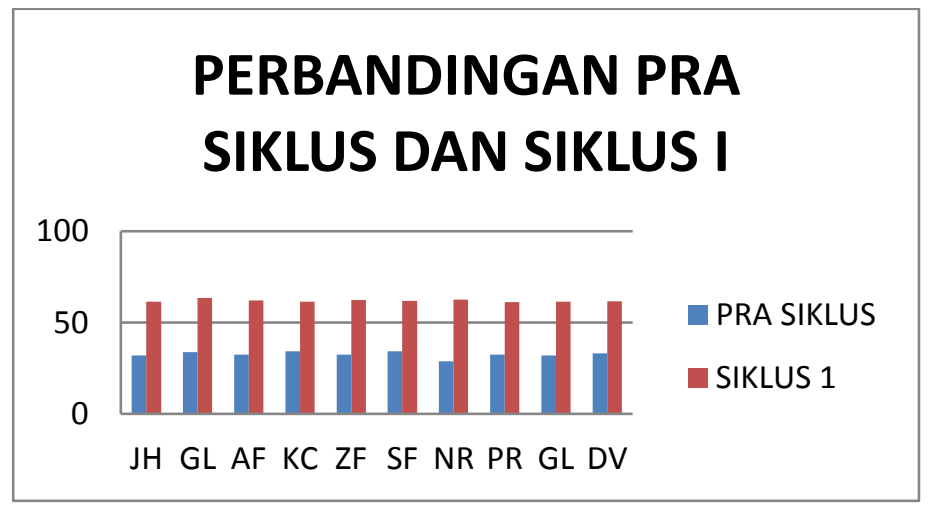

Gambar 2. Grafik Hasil Asesmen pengetahuan pola makan sehat Siklus I

Berdasarkan hasil tabel dan grafik di atas, diperoleh data tentang pengetahuan anak tentang pola makan sehat melalui flash card pada pelaksanaan siklus I, yaitu rata-rata 10 anak 
dengan persentase $63,44 \%$ diperoleh oleh GL dan skor ratarata terendah dengan persentase $61,25 \%$ diperoleh oleh PR. Secara klasikal sebesar persentase $61,94 \%$ artinya pelaksanaan pada siklus I belum mencapai kriteria keberhasilan yang telah disepakati diawal bersama kolaborator dan mastery learning yang ada di sekolah yakni sebesar $71 \%$.

Maka peneliti melanjutkan ke siklus II, namun sebelum melanjutkan Peneliti dan kolaborator melakukan refleksi terlebih dahulu.Ada beberapa hal yang menjadi bahan refleksi peneliti dan kolaborator pada siklus I baik itu berupa kelemahan maupun kelebihan. Adapun hasil refleksi tersebut, yaitu:

1. Anak duduk belum membentuk huruf $U$ karena mereka penasaran dengan flash card yang dibawa oleh guru

2. Ketika guru menjelaskan ada anak yang tidak peduli dengan penjelasan guru.

3. Guru tidak menyampaikan tema pembelajaran pada saat akan mulai mengajar.

4. Guru belum memberikan kesimpulan

5. Beberapa anak merespon dengan cepat pertanyaan dari guru.

6. Anak-anak sangat tertarik ketika guru memberikan reward kepada anak ketika anak mampu menjawab pertanyaan guru.

\section{Siklus II}

Adapun hasil dari siklus II adalah sebagai berikut:

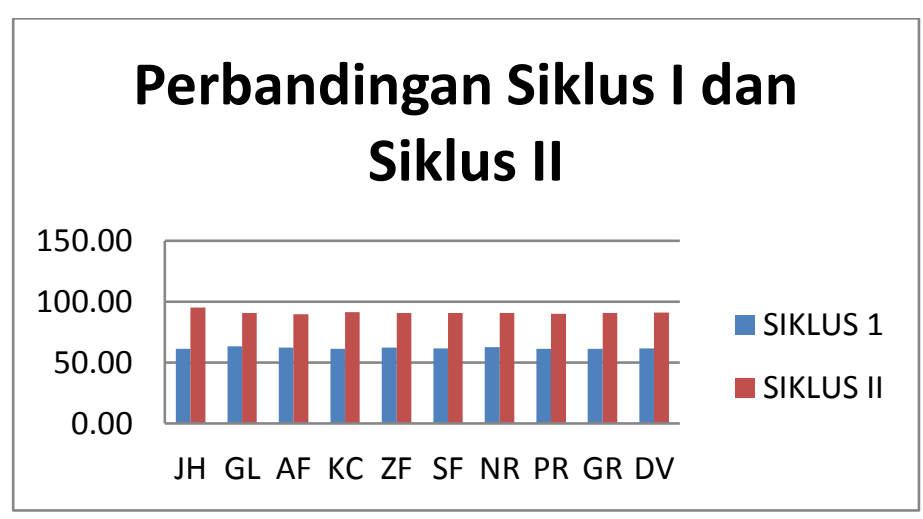

Gambat 3. Grafik Hasil Asesmen pola makan sehat Siklus II 
Berdasarkan hasil tabel dan grafik di atas, diperoleh data tentang pola makan sehat pada siklus II dari 10 anak secara klasikal memiliki persentase $91,17 \%$ artinya pelaksanaan pada siklus II terjadi peningkatan maka dari dapat diambil kesimpulan bahwa pelaksanaan siklus II telah melebihi nilai yang telah disepakati bersama kolaborator dan mastery learning yang ada di sekolah yakni sebesar $71 \%$ sehingga proses peningkatan pola makan sehat melalui flash card dapat dikatakan berhasil.

Berikut hasil asesmen pengetahuan pola makan sehat pada pra siklus, siklus I hingga siklus II

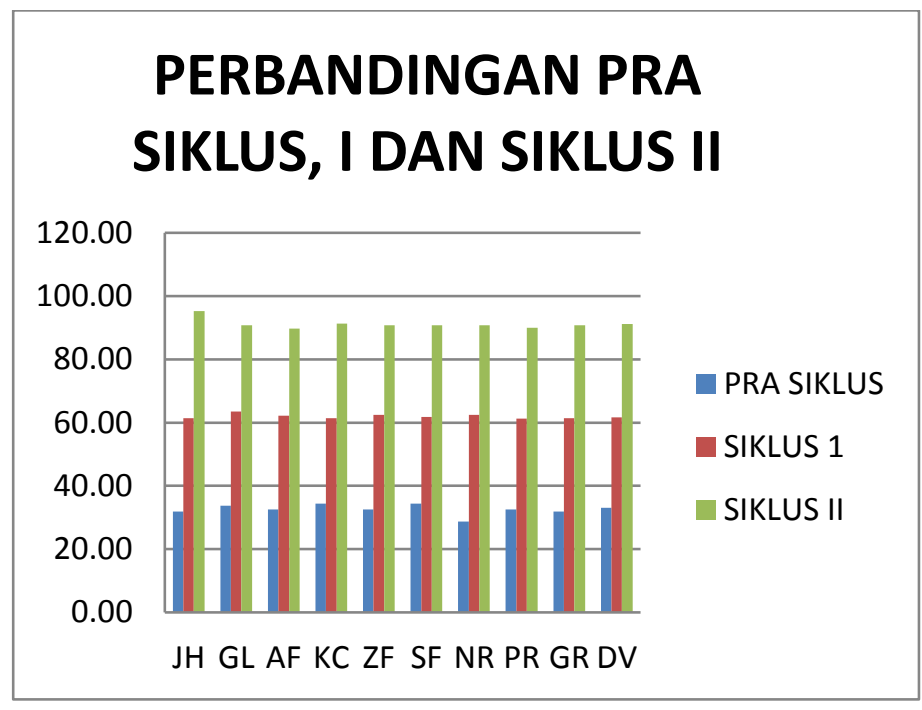

Gambar 4. Grafik Perbandingan Pola Makan Sehat PraSiklus, Siklus I dan Siklus II

Berdasarkan data di atas terlihat bahwa skor rata-rata persentase sebesar $32,57 \%$ pada pra siklus. kemudian mengalami peningkatan pada siklus I $29,37 \%$ sehingga menjadi 61,94\%, selanjutnya dari siklus I ke siklus II pengetahuan pola makan sehat pada anak mengalami peningkatan sebesar 29,23\% menjadi sebesar $91,17 \%$. Sehingga total peningkatan pola makan sehat pada anak melalui flash card mulai dari pra siklus, siklus I sampai siklus Il sebesar $58,60 \%$. 
Berdasarkan uraian di atas dapat disimpulkan bahwa flash card dapat meningkatkan pengetahuan pola makan sehatkelompok B TK Al HubKebayoran Baru Jakarta Selatan.

Berdasarkan perolehan data secara kuantitatif dan kualitatif, hasil penelitian ini telah membuktikan bahwa flash card dapat meningkatkan pengetahuan pola makan sehat pada anak Kelompok B TKAI HubKebayoran Baru Jakarta Selatan. Hasil penelitian menunjukan bahwa flash card sebagai usaha untuk meningkatkan pola makan sehat yang dilakukan dari siklus I dan II semakin baik sehingga terjadi adanya peningkatan secara kuantitatif yaitu skor rata-rata persentase sebesar $32,57 \%$ pada Pra Sikluskemudian mengalami peningkatan pada siklus I $29,37 \%$ sehingga menjadi $61,94 \%$, selanjutnya dari siklus I ke siklus II pengetahuan pola makan sehat pada anak mengalami peningkatan sebesar 29,23\% menjadi sebesar $91,17 \%$. Sehingga total peningkatan pola makan sehat pada anak melalui flash card mulai dari pra siklus, siklus I sampai siklus || sebesar 58,60\%.

Pengetahuan pola makan sehat meliputi enam aspek yaitu makanan sehat, makanan pokok, lauk pauk, sayur-sayuran, buah dan susu yang ditunjukan anak pada saat penelitian merupakan modal dasar bagi anak untuk memiliki pola hidup yang sehat. Bila ditinjau dari berbagai kajian ilmu maka pengetahuan pola makan sehat melalui flash card ada hubungannya dengan berbagai disiplin ilmu. Diantaranya dalam bidang pendidikan menurut Desmita dalam teori pieget menjelaskan bahwa anak yang berusia 2-7 tahun anak mulai mempersentasikan dunia dengan kata-kata dan gambargambar. Kata dan gambar menunjukan adanya peningkatan pemikiran simbolis dan melampui batas hubungan informasi sensor dan tindakan fisik (Desmita, 2012: 46). Sehingga dengan adanya pengetahuan pola makan sehat yang dikemas dalam flash card dapat memperoleh informasi sehingga akan mempengaruhi perilaku pola hidupnya dalam memilih makanan sehari-hari.

Tilaar dalam teori pembelajaran yang dikemukakan John Dewey mengatakan bahwa learning by doing (belajar dengan melakukan) (Tilaar, 2015: 146). Flash card tidak hanya mengajarkan pengetahuan pola makan sehat melalui ceramah tapi secara langsung mengajarkan kepada anak untuk melakukan dan memilih serta mengalami makan makanan sehat serta mengobservasi secara langsung macam-macam makanan sehat melalui gambar. Ini memberikan pengalamuan 
kepada anak sehingga mereka tahu makanan sehat itu seperti apa.

Dalam bidang kesehatan, kebutuhan dasar seorang anak adalah asah, asih dan asuh. Asah berhubungan dengan stimulasi atau pendidikan. Asih adalah kasih sayang, asuh adalah pemenuhan kebutuhan fisik dan rohani, hal ini berhubungan dengan kesehatan anak. Tujuan kesehatan bagi anak mencapai keadaaan kesehatan anak didik dan lingkungan hidupnya. Menurut Santrock pada umumnya masalah kesehatan yang sering dialami anak-anak adalah kurang gizi, pola makan dan kurang olah raga serta pelecehan. Sebagai praktisi pendidikan, guru dan orangtua pengetahuan pola makan sehat perlu diberikan anak sejak dini karena selain pola asuh, pola makan juga akan mempengaruhi tumbuh kembang anak.

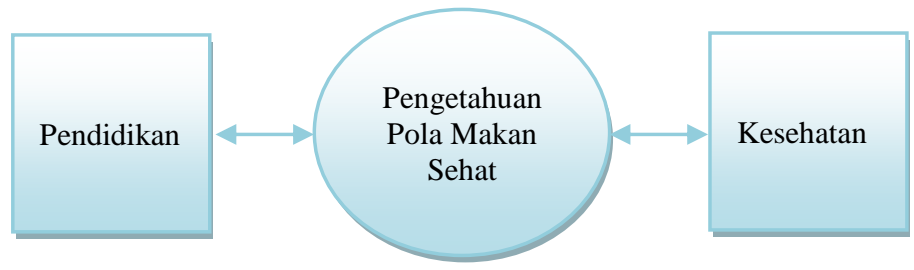

Gambar 5. Bagan Multidipliner Pengetahuan Pola Makan Sehat Melalui Flash Card

\section{KESIMPULAN}

Berdasarkan hasil analisis data dalam pembahasan, maka dapat disimpulkan bahwa Flash card dapat meningkatkan pengetahuan tentang pola makan sehatpada anak di TK B Al Hub Kebayoran Baru Jakarta Selatan. Hal ini dibuktikan dengan data hasil peningkatan pra siklus I, pelaksaan siklus I dan siklus II. Data hasil pelaksanaan kegiatan menunjukan peningkatan pengetahuan pola makan sehat yang enam aspek yaitu makanan sehat, makanan pokok, lauk pauk, sayursayuran, buah dan susu. Setiap anak mengalami peningkatan kemampuan sesuai dengan kriteria keberhasilan yang telah disepakati antara peneliti dan kolaborator.Secara kuantatif yaitu skor rata-rata persentase sebesar $32,57 \%$ pada pra siklus. kemudian mengalami peningkatan pada siklus I $23,37 \%$ sehingga menjadi $61,94 \%$, selanjutnya dari siklus I ke Siklus II pengetahuan pola makan sehat pada anak mengalami peningkatan sebesar 29,23\% menjadi sebesar $91,17 \%$. Sehingga total peningkatan pola makan sehat pada anak 
melalui flash card mulai dari pra siklus, siklus I sampai siklus II sebesar 50,68\%.

Berdasarkan kesimpulan dan implikasi di atas dapat disampaikan beberapa rekomendasi sebagai berikut:

1. Bagi guru diharapkan dapat membudayakan pola hidup sehat pada anak yang diawali dari makanan anak-anak.

2. Bagi orang tua, diharapkan orang tua anak dapat mendukung agar orang memberikan dan mengajarkan pola hidup sehat sejak dini, karena segala hal dimulai dari keluarga

3. Bagi peneliti lain diharapkan mau mengembangkan penelitian ini dan lebih banyak memperkaya sumbersumber yang mendukung baik itu secara nasional atau internasional

\section{REFERENSI}

Arsyad, Azhar, Media Pembelajaran, Jakarta: Rajawali Press, 2011

Almatsier, Sunita, Prinsip Dasar IImu Gizi(Jakarta: PT Gramedia Pusaka Utama, 2001

Akademi Gizi Departemen Kesehatan RI, Proyek Pengembangan Pendidikan Tenaga Gizi Pusat Jakarta

Bloom (Ed), Benjamin S. Taxonomy Of Educational Objectives: The Classification of Educational Goal Landon: Longman Group Ltd: 1994

Desmita, Psikologi Perkembangan Bandung: Rosdakarya, 2012

Indriana, Dina, Ragam Alat bantu Media Pengajaran, Yogyakarta: Diva Press, 2011

Notoatmojo, Soekidjo, Pendidikan dan Prilaku Kesehatan, Jakarta: PT Rineka Cipta, 2003

Persatuan Ahli Gizi Indonesia, Jakarta: RS Cipto Mangunkusumo, 1997

RantiAnne Lies dan Soegeng Santoso, Kesehatan dan Gizi, Jakarta: Rineka Cipta dan PT. Bina Adiaksara, 2004

Soekidjo, Notoatmodjo, Pendidikan dan Perilaku Kesehatan, Jakarta: Rineka Cipta, 2003 
ZUBAEDAH DAN DWI PUJI LESTARI

Suriasumantri, Jujun S. Filsafat IImu Sebuah Pengantar Populer Jakarta: Pustaka Sinar Harapan, 2005

Surajiyo, Filsafat IImu \& Perkembangannya di Indonesia Jakarta: Bumi Aksara, 2013

Tilaar, HAR Pedagogik Teoritis untuk Indonesia, Jakarta:

Kompas Gramedia, 2015 